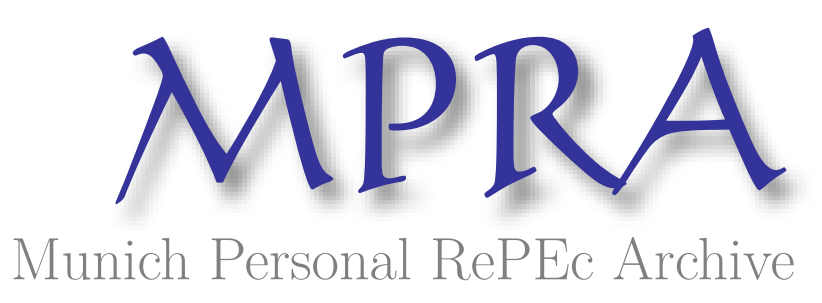

\title{
Corporate governance of financial intermediaries: convergence and divergence
}

Nedelchev, Miroslav

2012

Online at https://mpra.ub.uni-muenchen.de/64545/

MPRA Paper No. 64545, posted 25 May 2015 04:10 UTC 


\title{
CORPORATE GOVERNANCE OF FINANCIAL INTERMEDIARIES: CONVERGENCE AND DIVERGENCE
}

\author{
Miroslav Nedelchev ${ }^{*}$ \\ University of Veliko Turnovo, 2012 Academic Conference, pp. 324-333
}

\begin{abstract}
The paper reviews the corporate governance from his evolution point of view. The used perspective is a discussion between convergence and divergence in corporate governance of financial intermediaries. The discussion is core for researches in scientific and implementation papers for last fifty years.

Based on "principal-agent" model the paper illustrates both the dynamics of corporate governance and contemporary points of view for convergence and divergence of systems and practices.

The functional convergence for corporate governance of financial intermediaries outruns the formal convergence. The decisions at national and international level are responds to market reality. The globalization process is leading for convergence of corporate governance, until shareholders' ownership - for divergence.

The internal corporate governance is defined by path-dependence of the company. The revealed convergence concerns ownership rights and board accountability.

The external corporate governance is defined by the globalization. The auditors have convergence their practices for transparency to shareholders and investors. The regulators are convergent by requirements of stock exchanges.
\end{abstract}

JEL Classification: G32.

Keywords: corporate governance, financial intermediaries.

International Business School, Corporate Governance Program, Sofia 1303, 7 Chiprovtzi Str., Bulgaria. nedelchev.miroslav@acad.ibsedu.bg 


\section{Introduction}

Convergence (Latin convergere) means the approximation of systems and practices with a view to the achievement of a certain condition. For the needs of this report, ad hoc we assume that convergence means the approximation of systems and practices in corporate governance for the adaptation of financial intermediaries to the process of globalization.

Modern systems and practices in corporate governance are of two kinds: Continental and Anglo-Saxon [17, 4]. The basis for their classification is the relative importance of commercial banks and stock exchanges for corporate financing: the arm's length principle or control-oriented $[5,91]$. The functional approach to finances dwells upon two types of systems and practices from the viewpoint of reducing information asymmetry and expenditures $[25,688]$.

Divergence (Latin divergere) is an opposite of convergence. Divergence will mean the distancing of systems and practices in corporate governance in the process of the evolution of financial intermediaries.

Convergence and divergence are realized in functional and formal aspect [18, 11]. The common thing between the two aspects is the accountability of managers to shareholders for achieved financial results.

Functional convergence represents efficient integration of institutional components. It finds application at the presence of similar economic systems, for example, managers' accountability may be legislative required or unilaterally adopted [19, 32]. The purpose of this functional convergence is adaptability with regard to new requirements [7, 24]. This convergence is applied at the establishment and operation of a trans-sectorial financial group.

Formal convergence approximates the laws of individual countries. It is performed top-down and associated with difficulties at the application of normative rules in practice. Formal divergence is performed on the level of company law and securities regulation. When applying common law, the Anglo-Saxon system of corporate governance, financial intermediaries must conclude contracts under several legal norms. When applying civil law, the Continental system of corporate governance, more established by law rights exist and companies are less flexible in case of changes in external environment [29, 19]. This convergence finds application at the establishment and operation of a transnational financial group.

Because of the interaction between functional and formal convergence, spatial divergence arises, which is an objective result of economic development. Globalization, the spatial divergence, compels financial intermediaries to adopt common practices in corporate governance (functional and formal convergence) [23,43]. The spatial convergence of corporate governance requires changes in other areas, like regulation laws and tax laws [19, 23]. 
Since XIX century, company law has been converging on a global level. Normative convergence has five features that are typical of concrete legislation: legal personality, including a competent authority to close deals on behalf of a company; limited liability of shareholders; share ownership of capital investors; delegated management by a board; transferability of shares.

During XX century, convergence is a form of economic integration. According to the system theory, the convergence of financial systems is based on the configuration of complementary elements $[22,67]$. The convergence of financial systems is conceptualized over the process of the past dependence of institutional changes.

The convergence and divergence of corporate governance have been subject to researches since the start of regulating the international activity of financial intermediaries. The pioneer work of A. Gerschenkron (1962) explores the differences between the financial systems in Germany and Great Britain [17, 4]. After it, analysts expanded the scope of countries and included USA and Japan. Modern literature about convergence and divergence reviews the differences between the market-based and bank-based systems of corporate governance [22, 8].

The globalization of economics has changed the practices in corporate governance in the sector of financial services $[1,413]$. Two opposite opinions have formed. One group of authors thinks, that the different systems of corporate governance will draw closer to economically best practice $[9,641 ; 21,439]$. Another group of authors think, that similar convergence will not take place, due to the past dependence of individual companies [4, 127; 32, 233].

On an international level, the evolution of practices in corporate governance goes through three stages $[28,32]$.

The liberalization of the 1970's diverged the practices in individual countries through privatization programs. The majority shareholder, the state, admits external shareholders, but preserves the manager staff.

The deregulation of the 1980's converged the practices in individual countries through the adoption of a national corporate governance code. Because of this process, the requirements for public companies have been unified through reforms in stock exchanges. Deregulation has created more complex managerial structure and has increased the concentration of ownership [36, 421].

The globalization of the 1990's converged the practices in corporate governance through the leading role of supranational organizations. The main financial intermediaries, banks, have been converging their practices in corporate governance because of Basel Concordat (1988). The wave of entries into another financial sector, which has given rise to bankassurance, draws closer the 
practices of banks and insurance companies. Convergence is furthered by regulatory competition and supervisory harmonization $[19,46]$. „Convergence optimism” comes into existence.

For the sake of coping with the consequences of global recession, international organizations (G-20, the Organization for Economic Cooperation and Development, the World Bank) have taken a series of measures [27, 3]. Their efforts are focused on a reform in the corporate governance of financial intermediaries. Attention is focused on the introduction of new practices in the remuneration of managers for the balancing of assumed risk and long-term results. The authorities, responsible for the determination of international standards, stimulate convergence through the drawing-up of guidance books, based on principles, which are applicable on a global level. The concept is aimed at the transformation of financial results into a new model of ,stakeholder governance".

Convergence finds application as economic integration on a European Union level.

Since the 1950's, the main goal has been the attainment of social cohesion and harmonization of the development of individual regions. For European Union, the harmonization is an equivalent to a convergence $[33,93]$.

Since 1970's, the practices in corporate governance are a result of individual initiatives and particular national legislations. Company law harmonization of EU member-states is within the powers of the European Commission through proposals and directives.

During the 1980's, convergence was realized through the consolidation of stock exchange requirements for public companies. The adoption of the Second Banking Directive consolidated the Continental model of universal banking, including investment and commercial banking [13,2]. This directive repeals the harmonization ,one size fits all” to the market and self-regulating mechanisms for the creation of competitive environment [34, xi]. Modern literature reflects the understanding about ,one size does not fit all” of the adopted practices in corporate governance [20,7].

Since the 1990's, economic integration has been characterized by the introduction of the single currency (ECU). The realization of the Single Market Program has influence over the national markets in Europe and induces convergence in industrial structures between countries [16, 597]. The subsequent wave of mergers and takeovers reduced the role of banks and increased the importance of stock exchanges. Regardless of economic integration, the practices of corporate governance in the European Union diverge, as the differences between countries exceed the differences between economic sectors [40, 639].

Since the beginning of XXI century, voluntary corporate governance codes have come into force in the European Union. They are regarded unilaterally by financial intermediaries as a private 
case of deregulation. Self-regulation has been a signal of the necessity for global convergence of the standards between traditionally divergent national systems [26, 315].

The European Commission policy has been the application of national corporate governance codes, based on the principle „,comply or explain”. National codes contribute to the drawing-up of standards for the convergence of corporate governance between EU member-countries [15, 8]. Universal requirements have been set for the shareholders to exercise control over the actions of a board. Thanks to the applied national codes, convergence of the corporate governance policies in EU has been established $[31,20]$.

For the sake of coping with the consequences of economic recession, the European Commission suggested a new way of improving monitoring over corporate governance [14, 4]. Self-regulation has been defined as inefficient and replaced by pan-European rules, based on the EU Green Paper on the European Union corporate governance framework (2011). By means of the new framework, shareholders' responsibility for active participation is made equal through the exercise of the right to vote. The rules for higher convergence in the European Union will reduce the expenditures for the observation of national codes and will increase competitiveness on a panEuropean level.

On the level of Eastern Europe, the practices in corporate governance combine the characteristics of Continental practice, controlling shareholders, with elements of the Anglo-Saxon practice - defense of minority shareholders. Due to a transition to market economy, the application of good practices in corporate governance has been performed through privatization and market entry of considerable foreign companies. The basic agent conflict of interest is between controlling shareholders and minority shareholders and not between shareholders and managers, as it is with Anglo-Saxon practice [6, 11]. A leading factor of good practices in corporate governance is the stock exchange on which shares are quoted.

\section{Convergence and divergence of corporate governance components}

The existing great number of researches on the convergence and divergence of corporate governance can be summarized up to the analysis of systems and practices as a whole. The methodologies used do not operationalize up to the level of participants in corporate governance, as well as the used tools.

The present report deals with the individual components of corporate governance, which distinguishes it from approaches adopted so far. In the course of analysis, we shall adopt the model of ,principal-agent”. Due to the specific features of the corporate governance of financial 
intermediaries, we shall use the method SMART (Shareholders, Managers, Auditors, Regulators, Tools).

Shareholders of financial intermediaries, as a principal in corporate governance, are characterized by a high degree of convergence at the protection of their rights [35, 25]. The convergence of systems and practices is done through several elements of corporate governance. First, convergence is realized through the application of the principle „one share-one vote”, specific to the Anglo-Saxon practice of corporate governance. Following the trend towards an increase in the number of public companies, this principle has been modified into „one share-one vote-one dividend". Second, the protection of minority shareholders' rights is increased with the programs for privatization and deregulation, due to the concentration of ownership [12, 1].

Divergence is marked at the other elements of corporate governance. Shareholders' obligations continue to be determined by national legislations [40, 641]. The shareholders protection, in case of a merger, remains reduced in countries, having Continental practice in corporate governance, due to the poorly developed market of corporate control. The main reasons for divergence can be summarized to structural and systematic red tapes $[4,128]$. Structural red tapes are created by the presence of a different type of ownership, regardless of the convergence of national laws. Two types of past dependence are related to systematic red tapes: determined by the structure and determined by the rules for corporate governance. Namely, past dependence, defined by rules, explains the presence of different shareholding structures, without the applicable laws being converged.

Foreign shareholders have not lived up to the expectations for convergence of corporate governance at the acquisition of ownership in Eastern Europe. They are not inclined to export better practices in corporate governance to the host country [24, 32]. Analyses do not find a proof that institutional investors and capital markets carry out a promotion of "good practices" in Eastern Europe $[41,230 ; 2,415]$. Because they draw on the foreign experience of several countries, national practices remain divergent.

Managers of financial intermediaries, as an agent in corporate governance, note the divergence of the types of board, due to differences in shareholding structure [19, 82].

Convergence is realized with regard to the accountability of managers to the general meeting of shareholders for achieved financial results. For all countries and sectors, convergence to an increase in the board structure and information disclosure is noticeable [40, 651].

Convergence has two opposite diffusions. On the one hand, the application of the Continental corporate governance system for separation of management from control through an independent 
board is on the rise and there is an increase in the importance of stakeholders' model [37, 31]. On the other hand, there is an increase in the application of the Anglo-Saxon corporate governance system for the compulsory introduction of independent directors and committees, performing supervisory functions $[38,4]$.

After the reforms carried out in pension legislation, the Anglo-Saxon corporate governance system began to be applied also in Continental practice through an increase in the number of independent directors and separation of the chief executive officer from the chairman of the board [28, 42]. Regardless of the harmonization of national laws in the European Union, we still report divergence of the correlation between the number of external directors in the board, the independence of the chairman of the committees, performing supervisory functions, and the requirements for education and the experience of the chairman of the board $[8,12]$.

Auditors note convergence in their line of business through the application of the relevant International Financial Reporting Standards [39, 23]. The main goal, at the development of international standards, is transparency and comparability of reported financial information about investors to exist on a global scale, so that they will be able to invest efficiently their capital.

Normative convergence started in 2005 through joint working programs for convergence of national accounting principles and standards with the competent authorities of Japan, Canada, and USA. The cooperation between these authorities in USA and the European Union has led to convergence in the area of accounting and auditing, but not in the field of corporate governance [11, 291].

Regulators make a note of convergence at their activity as a result of globalization. The highest degree of convergence is reported at the practices of regulators in securities legislation, while differences still exist in terms of company law $[9,41]$.

The convergence of practices finds application in the cooperation of regulators from the home and host country. The aim of convergence is prudential regulation over international financial groups on a consolidated basis [3, 23].

For global convergence of regulatory practices, G-20 created „Private Sector Taskforce of Regulated Professions and Industries" (2011). The function of the new group of regulators is to present analyses and recommendations to regulators for the economic stability of world capital markets $[30,2]$. The basic motivation for the improvement of regulatory coordination is the effect minimization of systematic risk, due to incompatible regulatory engagements. Global regulatory convergence is a means for the achievement of international competition, the presentation of 
transparent information about the users of financial services and clearer exposure to view of the regulatory regimes for market players in the world.

Tools at the corporate governance of financial intermediaries are the establishment of audit committees and the exercise of control over rating agencies.

As a result of a series of failures at the application of accountancy practices, these practices are converged through the introduction of the Anglo-Saxon concept of an audit committee [10,8]. In 1996, the European Commission published a Green Paper "The role, the position and the liability of the statutory auditor within the European Union", in which audit committees are an important part of board makeup. The reasons for the adoptation of audit committees are associated with the integration and updating of company law with regard to the requirements of business, markets, and society.

The Anglo-Saxon practice of the participation of rating agencies in corporate governance is applied in Continental practice after the adoption of amendments to pension legislation and the wave of registrations on foreign stock exchanges. After the beginning of the global financial crisis, the rating agencies on the territory of the European Union are registered and regulated by the Committee of European Securities Regulators.

\section{Conclusions}

When arriving at conclusions, it may be asserted, that at the corporate governance of financial intermediaries, the functional convergence outdistances the formal one. The actions taken, on a national and supranational level for the convergence of practices, are in response to market reality. Globalization is a key factor for the convergence of corporate governance and shareholders ownership - for its divergence.

The convergence between sectors outdistances the convergence between countries. Functional convergence, the approximation of practices in corporate governance at trans-sectorial financial groups, outrun the formal convergence, typical of transnational financial groups.

When conducting future researches, it is recommended to dwell upon the individual composite parts of corporate governance. The attempt made for an analysis shows, that the dilemma between convergence and divergence at the corporate governance of financial intermediaries is determined by shareholders ownership.

The internal participants in corporate governance determine their practices, depending on the past dependence of a company. Shareholders bring their views and proposals closer with respect to ownership protection and the associated with it property and non-property rights. Managers 
converge with regard to accountability to shareholders and for transparency to investors, but diverge in terms of board makeup.

External participants in corporate governance have their practices converged, as a result of globalization. Auditors get converged with respect to the universal transparency to shareholders and investors. Regulators get converged through stock exchange requirements.

\section{References}

1. Abdesselam, R., S. Cieply, A.-L. Le Nadant. Transfers of Ownership Rights: An Empirical Study of Five European Countries. Brussels Economic Review, Vol. 51, № 4, Winter, 2008, pp. 413-434.

2. Aguilera, R., A. Cuervo-Cazurra. Codes of Good Governance Worldwide: What is the Trigger? Organization Studies, № 25, 2004, pp. 415-443.

3. Basel Committee on Banking Supervision. Principles for home-host supervisory cooperation and allocation mechanisms in the context of Advanced Measurement Approaches (AMA). November 2007.

4. Bebchuk, L., M. Roe. A theory of path dependence in corporate ownership and governance. Stanford Law Review, Vol. 52, 1999, pp. 127-170.

5. Berglöf, E. Corporate Governance Reform - Redirecting the European Agenda. Economic Policy, April, 24, 1997, pp. 91-124.

6. Berglöf, E., A. Pajuste. Corporate Governance in Central and Eastern Europe. in P. Cornelius, B. Kogut. Global Competitiveness and Corporate Governance. Oxford University Press. 2003.

7. Bratton, W., J. McCahery. The Case Against Global Cross Reference. in: McCahery J., P. Moerland, T. Raaijmakers, L. Renneboog (eds.). Corporate Governance Regimes Convergence and Diversity. Oxford University Press. 2002.

8. Challenging board performance. European Corporate Governance Report 2011. Heidrick \& Struggles International, Inc. 2011.

9. Coffee, J. The future as history: the prospects for global convergence in corporate governance and its implications. Columbia University School of Law, Working paper 144, 1998.

10. Collier, P., M. Zaman. Convergence in European Governance Codes: The Audit Committee Concept. Blackwell Journal: Corporate Governance: an international review, Nov-2005, 13 (6), pp. 753-768.

11. Dewing, I., P. Russell. Accounting, Auditing and Corporate Governance of European Listed Countries: EU Policy Developments Before and After Enron. Journal of Common Market Studies, 42 (2), 2004, pp. 289-319. 
12. Earle, J., S. Estrin. Privatization, Competition, and Budget Constraints: Disciplining Enterprises in Russia. Economics of planning, 36 (1), 1998, pp. 1-22.

13. European Commission. Financial Services: Implementing the Framework for Financial Markets: Action Plan. Communication from the Commission COM (1999), 1999.

14. European Commission Looks to Improve Corporate Governance. 2011.

15. Financial Reporting Council. Effective Corporate Governance. 2011.

16. Geroski, P., K. Gugler. Corporate Growth Convergence in Europe. Oxford Economic Papers, Volume 56, 2004, pp. 597-620.

17. Gerschenkron, A. Economic Backwardness in Historical Perspective. Harvard University Press. Cambridge Mass. 1962.

18. Gilson, R. Globalizing Corporate Governance: Convergence of Form or Function. Stanford Law and Economics Olin Working Paper № 192, May 2000.

19. Gordon, J., M. Roe. Convergence and persistence in corporate governance. Cambridge University Press. 2004.

20. Gregory, H. Comparing Corporate Governance Principles \& Guidelines. Weil, Gotshal \& Manges LLP, 2012.

21. Hansmann, H., R. Kraakman. The end of history for corporate law? Yale Law School Working Paper № 235, 2000.

22. Hölzl, W. Convergence of financial systems: towards an evolutionary perspective. Journal of Institutional Economics. Volume 2, 2006, pp. 67-90.

23. Khanna, T. Globalisation and Convergence in Corporate Governance. Harvard Business School, November 2001.

24. Klapper, L., L. Laeven, I. Love. What drives corporate governance? Firm-level evidence from Eastern Europe. Policy Research Working Paper Series 3600, World Bank. 2005.

25. Levine, R. Financial development an economic growth: views and agenda. Journal of Economic Literature, 35, 1997, pp. 688-726.

26. Lütz, S., D. Eberle, D. Lauter. Varieties of private self-regulation in European capitalism: corporate governance codes in the UK and Germany. Socio-Economic Review, Volume 9, Number 2, 2011, pp. 315-338.

27. McRitchie, J. Governance After the Financial Crisis. 2011.

28. Mullineux, A. Financial Sector Convergence and Corporate Governance. An European Perspective. Springer, 2002.

29. Nestor, S., J. Thompson. Corporate Governance Patterns in OECD Economies: Is Convergence Underway? OECD, Paris, 2000. 
30. Private Sector Taskforce of Regulated Professions and Industries. Regulatory Convergence in Financial Professions and Industries. Final Report to G-20 Deputies. 2011.

31. Financial Reporting Council. Riskmetrics study commissioned by the EU commission: Study on monitoring and enforcement practices in corporate governance in the Member States. 2009.

32. Roe, M. Corporate Law's Limits. Journal of Legal Studies, 31(2), 2002, pp. 233-271.

33. Schaede, U. Toward a New System of Corporate Governance in the European Union: An Integrative Model of the Anglo-American and Germanic Systems. European and Transatlantic Studies, 1995, pp. 93-119.

34. Scharpf, F. Governing in Europe: Effective and Democratic. Oxford University Press. 1999.

35. Siems, M. Convergence in Shareholder Law. Cambridge University Press, 2008.

36. Stacey, K., K. Lehn. Deregulation, the Evolution of Corporate Governance Structure, and Survival. American Economic Review Papers and Proc., 87, 1997, pp. 421-425.

37. Thomsen, S. Convergence of Corporate Governance Systems to European and Anglo-American Standards. European Business Organization Law Review, 4, 2003(1), pp. 31-50.

38. Walker, D. Walker Review of Corporate Governance of UK Banking Industry. 2009.

39. Willemain, J. Corporate reporting: Trends and tensions in convergence. Deloitte, 2008.

40. Wójcik, D. Convergence in corporate governance: evidence from Europe and the challenge for economic geography. Journal of Economic Geography, 6(5), 2006, pp. 639-659.

41. Wymeersch, E. Convergence or Divergence in Corporate Governance Patterns in Western Europe? In McCahery, J., P. Moerland, T. Raaijmakers, L. Renneborg, (eds.). Corporate Governance Regimes: Convergence and Diversity, Oxford, Oxford University Press, 2002, pp. 230250. 